\begin{tabular}{|c|l|}
\hline \multicolumn{1}{|c|}{ 「北極観測および北極域における自然利用とエネルギー資源開発のための科学技術」 } \\
2020 年度 年次報告書
\end{tabular}

\title{
1. 日本側の研究実施体制
}

\begin{tabular}{|l|l|l|}
\hline \multicolumn{1}{|c|}{ 氏名 } & \multicolumn{1}{|c|}{$\begin{array}{c}\text { 所属機関・部局・役職 } \\
\text { 役割 }\end{array}$} \\
\hline 松山 洋 & $\begin{array}{l}\text { 東京都立大学・都市環境科学 } \\
\text { 研究科・教授 }\end{array}$ & $\begin{array}{l}\text { 研究の総括 } \\
\text { WP1 および WP2 の実施 }\end{array}$ \\
\hline 川東正幸 & $\begin{array}{l}\text { 東京都立大学・都市環境科学 } \\
\text { 研究科・准教授 }\end{array}$ & WP4 の実施 \\
\hline 中山大地 & $\begin{array}{l}\text { 東京都立大学・都市環境科学 } \\
\text { 研究科・助教 }\end{array}$ & WP3 の実施 \\
\hline 渡邊貴典 & $\begin{array}{l}\text { 東京都立大学・都市環境科学 } \\
\text { 研究科・特任研究員 }\end{array}$ & WP1 WP4 の補助 \\
\hline
\end{tabular}

\section{2．日本側研究チームの研究目標及び計画概要}

本研究の目的は、シベリアの極地および山岳地域において増加している水文、気象の極端 現象が炭素および水循環に及ぼす影響に関して、地域間の比較研究を通じて明らかにするこ とである。この目的を達成するために研究開始当初、日本側チームが立てた 2020 年度の研 究目標及び計画概要は以下の通りであつた。 
(WP1)

極端な大気現象に関して、ロシア国内における西シベリアの地域的な特徵について明らか にする。また、極端な大気現象の発生に関する現状分析、およびこれが将来どのように発生 するかに関するシナリオ分析を行なう。IPCC 第 5 次評価報告書 (AR5) で述べられている、 ロシア国内でこれまでに発生してきた極端な大気現象の特徵が西シベリアにもあてはまる のかを観測データに基づいて確認する。その後、地球温暖化時に西シベリアで発生するであ ろう極端な大気現象の発生について考察する。

(WP2)

タンクモデルを用いて試験流域における水循環過程をモデル化し、極端な大気現象が水循 環（洪水や渇水）に及ぼす影響について考察する。また、2012 年は極端な渇水年であつた ため、この年に極端な大気現象が発生していないか調べる。さらに、極端な大気現象と洪水 発生との関係は 3 パターン考えられるため（融雪洪水+春季の高温化; 融雪洪水+春季の雨 量増加; 夏季の水河融解+雨量増加）、近年、いずれのパターンが卓越しているのかを、水文、 気象データの解析とタンクモデルの感度分析を行なうことで明らかにする。

(WP3)

現在整備中である土地条件の教師データに、衛星画像とデジタル地形データから計算した 地形変量、他の WP で得られた変数を加え、機械学習（決定木、ランダムフォレスト）を用 いたランドスケープ分類モデル・地形分類モデルを作成する。また、トムスク市周辺で近年 発生した地形災害インベントリを作成し、これを教師データとして、機械学習による地形災 害発生予測モデルを作成する。研究成果は、リアルタイム意思支援決定システムとして、ト ムスク国立大学の Web Site を通じて公開する。

(WP4)

試験流域においては、泥炭分布域から沼沢水が流入していたり、少雨・旱䰠後の強雨によ って林地から高濃度の溶存有機物が流出していたりする可能性があり、これらの仮説の妥当 性について検証する。そのため、極端現象の影響を受けた地域にモ二タリング機器を設置で きるか検討し、融雪機を含む時期に現地調査を行なう。また、河川水の溶存有機物に及ぼす 植生帯の貢献度を算出し、貢献度の高い植生帯における環境変化について考察する。最終的 には、気象・水文の極端現象が炭素循環に及ぼす影響について考察する。

\section{3. 日本側研究チームの実施概要}

2. で挙げた研究目標に関して、2020 年度に日本側チームが行なった研究の概要は以下 の通りである。

(WP1)

ロシア国内の観測データ（1950～2019 年）を用いて、極端現象に関する 27 指標 (WMO) を計算し、ロシアにおける西シベリアの地域的特徵を明らかにした。西シベリアでは春季の 気温の上昇傾向が特に大きく融雪の時期を早めていること、アルタイ山脈周辺では比較的強い雨 が降りやすくなっており、春季から夏季にかけてその傾向が顕著であることが明らかになった。 極端な大気現象の将来予測については、「地球温暖化対策に資するアンサンブル気候予測データ ベース」に基づいて検討することにし、計算および解析にどの程度時間がかかるかを検討した。 
(WP2)

西シベリアの 3 つの流域における水文・気象データを用いて、タンクモデルで降雪 - 積雪 一融雪－流出過程をモデル化した。積雪深の季節変化はよく再現されたが、融雪期／暖候期 の流出量が過小/過大評価された。この原因の一つとして、タンクモデルが集中型モデルで あることが考えられた。また、極端な大気現象と洪水発生との関係として、「融雪洪水+春 季の高温化」が発生している可能性が高いことが示された。なお、2012 年（極端な渴水年） の事例解析には着手できなかったが、データは揃っているため、2021 年度に解析を行なう。

(WP3)

衛星画像ならびに数值標高モデルを用いてトムスク地域の土地条件判別モデルを作成し た。作成手法としてはランダムフオレストを用いた。説明変数として、2013 年から 2019 年の正規化積雪指標の最大値コンポジット、正規化植生指標の最大値コンポジット、数值標 高モデルから計算した地形量を使用した。目的変数としてはカウンターパートから入手した 土地条件ポリゴンデータを用いた。その結果、リファレンスデータのある場所は過学習であ ったが、リファレンスデータのない場所については定性的には良好な判別結果となった。

(WP4)

異常気象や火災等の流域林地内における極端現象を把握するために試験流域における現 地モ二タリングを計画していたが、実施できなかつた。そこで、ロシア側研究者が取得した 2019 年度のデータを再解析した。その結果、流域河川における溶存有機物濃度、亜硝酸態 窒素濃度、リン酸濃度の定常状態を把握し、それらが概ね流量に依存していること、これに 対して夏季に突発的に高い硝酸濃度が観測されていることがわかった。この原因について、 他の期間・流域データおよび気象デー夕等と照合し追及する予定である。 